\title{
PENGARUH PENDIDIKAN KESEHATAN TERHADAP PENGETAHUAN MASYARAKAT AWAM DI RSUP DR. HASAN SADIKIN TENTANG KANKER BULI
}

\author{
Sri Suryanti' ${ }^{1}$, Hasrayati Agustina ${ }^{1}$, dan Sri Mulyati ${ }^{1}$ \\ ${ }^{1)}$ Departemen Patologi Anatomik, Fakultas Kedokteran Universitas Padjadjaran \\ E-mail: yanti.patologi@gmail.com
}

\begin{abstract}
ABSTRAK. Kanker buli adalah masalah kesehatan masyarakat internasional dan peringkat ke lima keganaan terbanyak dan penyebab kematian tertinggi kedua karena keganasan di saluran kemih di negara-negara maju. Keterlambatan dalam diagnosis kasus kanker buli sering terjadi. Salah satu penyebab keterlambatan dalam diagnosis kanker buli adalah interval waktu ketika pasien pertama kali mengetahui gejala penyakit yang terjadi dengan saat pertama berkonsultasi tentang keluhannya kepada tenaga medis. Salah satu upaya untuk meningkatkan kesadaran individu terhadap kondisi tertentu adalah melalui upaya meningkatkan pengetahuan dalam bentuk penyuluhan kesehatan tentang kanker buli. Tujuan dari penelitian ini adalah untuk menentukan perubahan tingkat pengetahuan masyarakat awam tentang kanker buli melalui penyuluhan kesehatan. Penelitian ini menggunakan metode penelitian kuasi-eksperimental dengan desain "satu kelompok pretest-postest". Sebelum penyuluhan, mayoritas responden, 56,7\%, memiliki pengetahuan kurang sementara setelah penyuluhan, pengetahuan meningkat secara signifikan.
\end{abstract}

Kata kunci: penyuluhan kesehatan, kanker buli, pengetahuan

ABSTRACT. Bladder cancer is an international public health problem and ranks the fifth most malignancy and the second highest cause of death due to malignancy in the urinary tract in developed countries. There is often a delay in diagnosis in cases of bladder cancer. One of the causes of delay in the diagnosis of bladder cancer is the time interval when the patient is first aware of the symptoms of the disease that occurred and at the first time to consult about his complaint to medical personnel. One effort to increase individual awareness of certain conditions is through efforts to increase knowledge in the form of health education about bladder cancer. The aim of tis study is to determined the change in the level of public knowledge about bladder cancer through health education.This study used a quasiexperimental research method by "one group pretest-posttest design". Before the counseling, majority of respondens, 56.7\%, have less knowledge while after health education the knowledge increased significantly.

Key words: health education, bladder cancer, knowledge

PENDAHULUAN

Kanker buli merupakan masalah kesehatan masyarakat internasional. Masalah ini terutama berkaitan dengan pengaruh kanker buli ini terhadap kualitas hidup pasien dan keluarganya, biaya yang diperlukan dalam penanganan penyakit serta bahaya kematian yang harus dihadapi. (Mahdavifar, Ghoncheh, Pakzad, Momenimovahed, \& Salehiniya, 2016)

Kanker buli adalah keganasan yang sebagian besar berasal dari mukosa buli atau kandung kemih (urotelium). Kanker ini merupakan keganasan kelima paling sering dan penyebab kematian urutan keduatertinggi akibat keganasan pada saluran kemih di negara berkembang. (Kang et al., 2017)

Diagnosis kanker buli ditentukan berdasarkan keluhan, tanda dan gejala, pemeriksaan fisik, dan pemeriksaan penunjang. Pemeriksaan sistoskopi dan biopsi/ reseksi merupakan standar diagnostik untuk kanker buli. Diagnosis pasti ditegakkan berdasarkan hasil pemeriksaan patologi anatomik.(Umbas et al., 2014)

Angka kekambuhan kanker buli ini cukup tinggi dan memerlukan pemantauan secara berkala yang membutuhkan biaya tinggi.(Umbas et al., 2014)

Kejadian kanker buli berkaitan dengan faktor risiko lingkungan. Faktor tersebut antara lain merokok, pajanan bahan kimia industri, air minum yang terkontaminasi klorin dan arsen serta riwayat kanker buli pada keluarga.
Sebagian besar faktor risiko tersebut dapat diatasi dengan modifikasi pola hidup serta perlindungan lingkungan. (Mahdavifar et al., 2016)(Umbas et al., 2014).(Wong, Fung, Leu, Cheung, \& William, 2018)

Prognosis kanker buli ditentukan oleh derajat dan stadium lesi. Keterlambatan diagnosis dan penata-laksanaan dapat mengubah keseluruhan luaran pada pasien kanker buli sehingga deteksi dini serta program penapisan memiliki peran yang sangat penting dalam kasus ini. Sedangkan saat ini, belum ada program penapisan khusus bagi kasus kanker buli. Diagnosis terutama dilakukan berdasarkan keluhan pada pasien serta pemeriksaan kontrol kesehatan ketika terdapat kelainan pada pemeriksaan urin maupun pencitraan.(Khochikar, 2011)

Salah satu penyebab keterlambatan dalam diagnosis kanker buli adalah selang waktu saat pasien pertama kali menyadari gejala penyakit yang terjadi dan saat pertama kali untuk melakukan konsultasi mengenai keluhannya kepada tenaga medis.(Macleod, Mitchell, Burgess, Macdonald, \& Ramirez, 2009)

Salah satu upaya untuk meningkatkan kesadaran individu terhadap keadaan tertentu antara lain melalui upaya peningkatan pengetahuan berupa pendidikan kesehatan mengenai kanker buli.

Pendidikan kesehatan merupakan suatu upaya atau kegiatan untuk menciptakan perilaku masyarakat yang kondusif untuk kesehatan. Pendidikan kesehatan tidak hanya berpengaruh terhadap tingkat kesadaran atau 
pengetahuan masyarakat tentang kesehatan, namun yang lebih penting adalah mencapai perilaku kesehatan yang baik. (Lestari, 2010)

Melalui paparan informasi dalam pendidikan kesehatan mengenai kanker buli diharapkan masyarakat dapat lebih meningkatkan kewaspadaan terhadap gejala awal kanker buli yang harus segera ditindaklanjuti.

\section{METODE}

Populasi dalam penelitian ini adalah semua pengunjung di ruang tunggu Laboratorium Patologi Anatomik RSUP Dr. Hasan Sadikin Bandung dengan sampel yang diambil sebanyak 30 responden. Jenis penelitian ini adalah eksperimen semu (quasi experiment) untuk mengetahui apakah terdapat perbedaan pengetahuan tentang kanker buli pada masyarakat awam sebelum dan sesudah diberikan pendidikan kesehatan di Laboratorium Patologi Anatomik RSUP Dr. Hasan Sadikin. Rancangan pre-eksperimental yang digunakan adalah one group pre test-post test design.

Instrumen dalam penelitian ini adalah kuesioner penelitian untuk mengukur pengetahuan mengenai kanker buli. Bahan yang digunakan dalam penelitian ini adalah: materi pendidikan kesehatan dalam bentuk peralatan media visual untuk penunjang ceramah/penyuluhan.

Analisis data pada penelitian ini berupa uji statistik deskriptif. Statistik deskriptif merupakan statistik yang bertugas mendeskripsikan atau memaparkan gejala hasil penelitian. Uji statistik ini bertujuan mengetahui jumlah, persentase variabel pengetahuan.

Penelitian ini telah mendapatkan persetujuan etik dari Komite Etik Penelitian Universitas Padjadjaran dengan Nomor : 953/UN6.KEP/EC/2018.

\section{HASIL DAN PEMBAHASAN}

Data penelitian menunjukkan bahwa tingkat pendidikan responden sebelum diberikan materi informasi lewat metode penyuluhan sebagian besar termasuk kategori Kurang, 17(56,7\%). Sedangkan setelah diberikan materi penyuluhan persentase responden dengan kategori tingkat pendidikan Cukup dan Baik mengalami peningkatan menjadi $16(53.3 \%)$ dan $10(33.3 \%)$.

Tabel 1. Perbandingan skor total jawaban Pre-Test dan PostTest

\begin{tabular}{|c|c|c|c|}
\hline \multirow[b]{2}{*}{ Skor Total Jawaban } & \multicolumn{2}{|c|}{ Kelompok } & \multirow[b]{2}{*}{ Nilai P } \\
\hline & $\begin{array}{c}\text { Pre-Test } \\
\mathbf{n}=\mathbf{3 0}\end{array}$ & $\begin{array}{c}\text { Post-Test } \\
\mathbf{n}=\mathbf{3 0}\end{array}$ & \\
\hline & & & $0.0001 * *$ \\
\hline Mean \pm Std & $5.43 \pm 2.011$ & $7.43 \pm 2.095$ & \\
\hline Median & 5.00 & 8.00 & \\
\hline Range (min-max) & $2.00-9.00$ & $3.00-10.00$ & \\
\hline \multicolumn{4}{|c|}{$\begin{array}{l}\text { Keterangan: Untuk data numerik nilai } \mathrm{p} \text { diuji dengan uji } \mathrm{T} \text { berpasangan } \\
\text { apabila data berdsitribusi normal dengan alternatif uji } \\
\text { Wilcoxon apabila data tidak berdistribusi normal. Nilai } \\
\text { kemaknaan berdasarkan nilai } \mathrm{p}<0,05 \text {. Tanda* menunjukkan } \\
\text { nilai } \mathrm{p}<0,05 \text { artinya signifkan atau bermakna secara statistik }\end{array}$} \\
\hline
\end{tabular}

Untuk analisis data Numerik ini diuji dengan menggunakan uji $\mathrm{T}$ berpasangan apabila data berdistribusi normal serta alternatif uji Wilcoxon apabila data tidak berdistribusi normal yaitu Skor total Jawaban. Hasil uji statistik pada kelompok penelitian di atas diperoleh informasi nilai P pada variabel Skor total Jawaban lebih kecil dari 0.05 (nilai $\mathrm{P}<0.05$ ) yang berarti signifikan atau bermakna secara statistik dengan demikian dapat dijelaskan bahwa terdapat perbedaan rerata yang signifikan secara statistik antara variabel Skor total Jawaban pada Pre dan Post-Test.

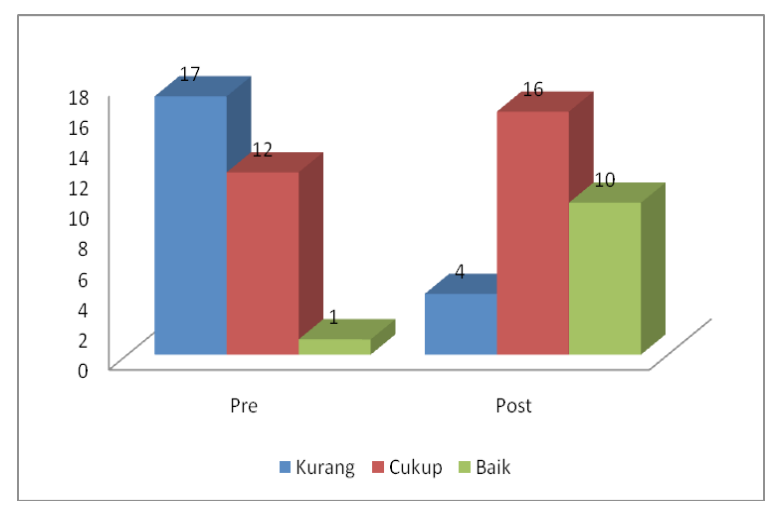

Gambar 1. Perbandingan antara skor total jawaban pre-test dan post-test

Beberapa pertanyaan pada kuesioner terdiri dari beberapa poin penting yang ingin disampaikan peneliti yaitu cara pencegahan kanker buli serta tindakan awal untuk mengantisipasi terjadinya kanker buli. Berdasarkan jawaban yang benar dari responden atas soal yang berkaitan dengan poin tersebut, tidak tampak perbedaan yang besar antara hasil post-test dibandingkan hasil pre-test. Hal ini kemungkinan disebabkan oleh tingkat pengetahuan awal masyarakat yang dalam hal ini adalah masyarakat perkotaan sehingga kemungkinan sudah banyak terpapar informasi mengenai kesehatan.

Titik berat perbedaan hasil pre-test dan post-test terutama meliputi soal-soal kuesioner yang berhubungan dengan detil penyakit. Walaupun hal ini bukan merupakan titik berat penyuluhan kali ini tetapi hal ini dapat memberikan gambaran seberapa besar pengaruh pendidikan kesehatan, penyuluhan, dalam penyampaian informasi kesehatan secara umum.

\section{SIMPULAN}

Data hasil penelitian menunjukkan bahwa pendidikan kesehatan dalam hal ini berupa penyuluhan dapat meningkatkan tingkat pengetahuan masyarakat tentang kanker buli.

\section{UCAPAN TERIMAKASIH}

Para penulis mengucapkan terima kasih kepada Universitas Padjadjaran untuk berkontribusi dalam pembiayaan penelitian ini melalui hibah internal UNPAD. Para penulis 
juga secara khusus berterima kasih kepada pusat studi On kologi dan Sel Punca UNPAD dalam memfasilitasi hal-hal mengenai pelaksanaan penelitian sampai proses publikasi.

\section{DAFTAR PUSTAKA}

Kang, H. O. W. O. N., Kim, Y. E. H., Jeong, P., Park, C., Kim, W. O. N. T. A. E., Ryu, D. H. E. E., Moon, S. K. (2017). Expression levels of FGFR3 as a prognostic marker for the progression of primary pT1 bladder cancer and its association with mutation status. Oncology Letters, (14), 38173824.

Khochikar, M. V. (2011). Rationale for an early detection program for bladder cancer. Indian Journal of Urology, 27(2), 218-225.

Lestari, D. (2010). Pengaruh Pendidikan Kesehatan terhadap Pengetahuan, Sikap dan Perilaku PSK dalam rangka Pencegahan IMS di Lokalisasi Gajah Kumpul Kabupaten Pati.Universitas Sebelas Maret.
Macleod, U., Mitchell, E. D., Burgess, C., Macdonald, S., \& Ramirez, A. J. (2009). Risk factors for delayed presentation and referral of symptomatic cancer: Evidence for common cancers. British Journal of Cancer, 101(S2), S92-S101.

Mahdavifar, N., Ghoncheh, M., Pakzad, R., Momenimovahed, Z., \& Salehiniya, H. (2016). Epidemiology, Incidence and Mortality of Bladder Cancer and their Relationship with the Development Index in the World, 17, 5-8.

Umbas, R., Hardjowijoto, S., Mochtar, C. A., Safriadi, F., Djatisoesanto, W., Agung, A., ... Hendri, A. Z. (2014). Panduan penanganan kanker kandung kemih tipe urotelial.

Wong, M. C. S., Fung, F. D. H., Leu, C., Cheung, W. W. L., \& William, B. (2018). The global epidemiology of bladder cancer : a joinpoint regression analysis of its incidence and mortality trends and projection, (January 2017), 1-12. 